\title{
Shear bond strength of self-etch and total-etch adhesives to bovine enamel and dentin
}

\author{
Resistência ao cisalhamento de adesivo autocondicionante e \\ convencional ao esmalte e dentina bovinos
}

\begin{abstract}
Purpose: To evaluate the shear bond strength of a self-etch adhesive and an etch-and-rinse adhesive when bonded to bovine enamel and dentin.

Methods: The labial surfaces of 28 bovine mandibular incisors were wet ground to achieve a flat enamel or dentin surface. A 1 -step self-etch adhesive and a 3-step etch-and-rinse adhesive were bonded to enamel or dentin according to the manufacturer's instructions (Adper Easy One and Adper Scotchbond, respectively). A composite resin cylinder (Filtek Z350 XT) was built upon the adhesive layer using a silicon mold ( $2 \mathrm{~mm}$ in diameter $\times 3 \mathrm{~mm}$ high). The specimens were stored in $37^{\circ} \mathrm{C}$ distilled water for $24 \mathrm{~h}$. The bond strength was measured by a universal testing machine at a crosshead speed of $1.0 \mathrm{~mm} / \mathrm{min}$. Student's $t$-test was used to compare bond strength values between adhesives at the $95 \%$ confidence level.

Results: For the_enamel specimens, Adper Scotchbond had significantly higher values of bond strength than Adper Easy One $(P=0.007)$. For the dentin specimens, there were no statistically significant differences between adhesives $(P=0.12)$.

Conclusion: Adper Easy One showed lower shear bond strength than Adper Scotchbond on enamel. For dentin, Adper Easy One showed bond strength similar to Adper Scotchbond.
\end{abstract}

Key words: Dental adhesives; self-etch; shear strength

\section{Resumo}

Objetivo: Avaliar a resistência ao cisalhamento de adesivo autocondicionante e adesivo convencional ao esmalte e dentina bovinos.

Metodologia: As superfícies vestibulares de 28 incisivos mandibulares bovinos foram lixadas, sob refrigeração, para obtenção de superfícies de esmalte ou dentina planas. Um adesivo autocondicionante de passo único e um convencional de três passos foram utilizados de acordo com as instruções dos fabricantes (Adper Easy One and Adper Scotchbond, respectivamente). Um cilindro de resina composta foi confeccionado sobre a camada adesiva usando um molde de silicone $\left(2 \mathrm{~mm}\right.$ de diâmetro $\times 3 \mathrm{~mm}$ altura). Os espécimes foram armazenados a $37^{\circ} \mathrm{C}$ em água destilada por $24 \mathrm{~h}$. A resistência de união foi mensurada através de máquina de ensaios universal à velocidade de $0.1 \mathrm{~mm} / \mathrm{min}$. Teste $t$ de Student comparou os resultados de resistência de união entre os adesivos com nível de confiança de $95 \%$.

Resultados: Para os espécimes de esmalte, Adper Scotchbond apresentou valores significativamente maiores que Adper Easy One $(P=0.007)$. Para espécimes de dentina, não houve diferenças significativas entre os adesivos $(P=0.12)$.

Conclusão: Adper Easy One mostrou menor resistência ao cisalhamento do que Adper Scotchbond no esmalte. Para dentina, Adper Easy One mostrou resistência de união similar ao Adper Scotchbond.

Palavras-chave: Adesivos dentários; autocondicionantes; resistência ao cisalhamento

\section{Carolina Carramilo Raposo a Ivone Lima Santana ${ }^{b}$}

\footnotetext{
a Post Graduate Program in Dentistry, Federal University of Maranhão, São Luís, MA, Brazil

${ }^{b}$ Department of Odontology I, Federal University of Maranhão, São Luís, MA, Brazil
}

\author{
Correspondence: \\ Ivone Lima Santana \\ Rua Queóps, Qd. 22, n 14 Apto 703 - Renascença II \\ São Luís, MA - Brasil \\ 65085-040 \\ E-mail: ilima@usp.br
}

Received: November 8, 2011

Accepted: April 17, 2012

Conflict of Interests: The authors state that there are no financial and personal conflicts of interest that could have inappropriately influenced their work.

Copyright: (C) 2011 Raposo \& Santana; licensee EDIPUCRS. This is an Open Access article distributed under the terms of the Creative Commons AttributionNoncommercial-No Derivative Works 3.0 Unported License. 


\section{Introduction}

The clinical performance of current adhesives has significantly improved to where resin restorations can be placed with a highly predictable level of clinical success (1). Among contemporary adhesives, self-etch adhesives have become popular, especially because of their ease of use and faster application (2).

Self-etch adhesives have the advantage to demineralize and infiltrate the tooth surface simultaneously to the same depth, decreasing the application time and technique sensitivity (3). Furthermore, patients treated with self-etch adhesives have shown less postoperative sensitivity $(4,5)$. These adhesives are available as either 2-step or 1-step, depending on whether a self-etching primer and adhesive resin are separately provided or are combined into a single solution (3).

Studies have shown that 1-step self-etch adhesives bonded to either enamel or dentin have relatively low bond strength. The mixture of water, solvents, and adhesive monomers into a 1-step self-etch adhesive resin may reduce the latter's mechanical properties and, accordingly, lessen bonding performance $(6,7)$.

Also, a recent meta-analysis has concluded that the 2-step self-etch adhesive system has superior in vitro performance compared with the 1-step self-etch system. The authors recommended that the newest adhesives be screened more strictly before clinical use (8). In terms of adhesion durability, the 3-step etch-and-rinse is considered the gold standard among bonding systems. Application of a solvent-free, neutral-pH, hydrophobic, adhesive resin layer in a separate step results in bonding effectiveness (9).

The purpose of this study was to compare the shear bond strength of a 3-step etch-and-rinse with a 1-step self-etch adhesive when bonded to bovine enamel and dentin. Our hypothesis was that self-etch adhesives would perform similarly to etch-and-rinse adhesives, which remain the gold-standard.

\section{Methods}

Twenty-eight bovine mandibular incisors were extracted, cleaned, and stored in $0.1 \%$ thymol at room temperature before the experiment. The labial surfaces were ground on wet, 150-grit silicon carbide $(\mathrm{SiC})$ paper to achieve a flat enamel or dentin surface. The roots of the teeth were cut at the cemento enamel junction using a low-speed diamond saw under water coolant. Each tooth was then mounted on cold-curing acrylic resin, exposing the flattened area. The specimens were polished using 400- and 600-grit $\mathrm{SiC}$ paper for $10 \mathrm{~s}$ to provide an uniform smear layer.

The specimens were randomly divided into 4 groups $(n=7)$. An etch-and-rinse adhesive (Adper Scotchbond, $3 \mathrm{M}$ ESPE, Sumaré, SP, Brazil) and a 1-step self-etch adhesive (Adper Easy One, 3M ESPE) were used in this study, bonded to enamel or dentin. The adhesive systems were used according the manufacturer's instructions and light-cured for $20 \mathrm{~s}$ at $500 \mathrm{~mW} / \mathrm{cm}^{2}$ (Ultraled, Dabi Atlante, Ribeirão Preto, SP, Brazil).

A composite resin cylinder (Filtek Z350 XT, 3M ESPE, Sumaré, SP, Brazil) was built upon the adhesive layer in 2 increments, using a silicon mold ( $2 \mathrm{~mm}$-diameter $\times 3 \mathrm{~mm}$ height). Each increment was light-cured for $20 \mathrm{~s}$ and, after removal of the mold, the composite resin was light-cured for $40 \mathrm{~s}$. The specimens were stored in $37^{\circ} \mathrm{C}$ distilled water for $24 \mathrm{~h}$.

The bond strength was measured by a universal testing machine at a cross-head speed of $1.0 \mathrm{~mm} / \mathrm{min}$ until failure and the maximum load at fracture was recorded. After the test, the debonded surfaces were observed with a stereomicroscope (Kozo Optical and Electronical Instrumental, Nanjing, Jiangsu Province, China) at $8 \mathrm{X}$ magnification to determine the mode of failure. The fractured surface was classified as 1 of 3 types: type 1, adhesive failure between bonding resin and dental substrate; type 2, cohesive failure in bonding resin; type 3 , cohesive failure in dental substrate.

The statistical analysis was performed with SPSS 16.0 (IBM SPSS Inc., New York, USA). A $t$-test for independent samples was used to compare bond strength values between adhesives at $95 \%$ confidence level.

\section{Results}

Table 1/ Graph 1 shows mean shear bond strength values (MPa) and their standard deviations; Table 2 shows failure modes. For the enamel specimens, the bond strength of Adper Scotchbond was significantly greater than that of Adper Easy One $(\mathrm{F}=2.12, \mathrm{df}=10, P=0.007)$. For the dentin specimens, there were no significant differences between adhesives $(\mathrm{F}=0.26, \mathrm{df}=11, P=0.12)$.

Table 1. Shear bond strength of adhesives tested in different substrates (mean \pm standard deviation)

\begin{tabular}{lcc}
\hline \multirow{2}{*}{ Dental Substrate } & \multicolumn{2}{c}{ Adhesive System } \\
\cline { 2 - 3 } & $\begin{array}{c}\text { Adper Scotchbond } \\
(\mathrm{MPa})\end{array}$ & $\begin{array}{c}\text { Adper Easy One } \\
(\mathrm{MPa})\end{array}$ \\
\hline Enamel & $17.02( \pm 5.91) \mathrm{a}$ & $8.82( \pm 2.28) \mathrm{b}$ \\
Dentin & $15.81( \pm 5.48) \mathrm{a}^{*}$ & $11.67( \pm 3.4) \mathrm{a}^{*}$ \\
\hline
\end{tabular}

* Same letter indicates statistical similarity $(P>0.05)$.

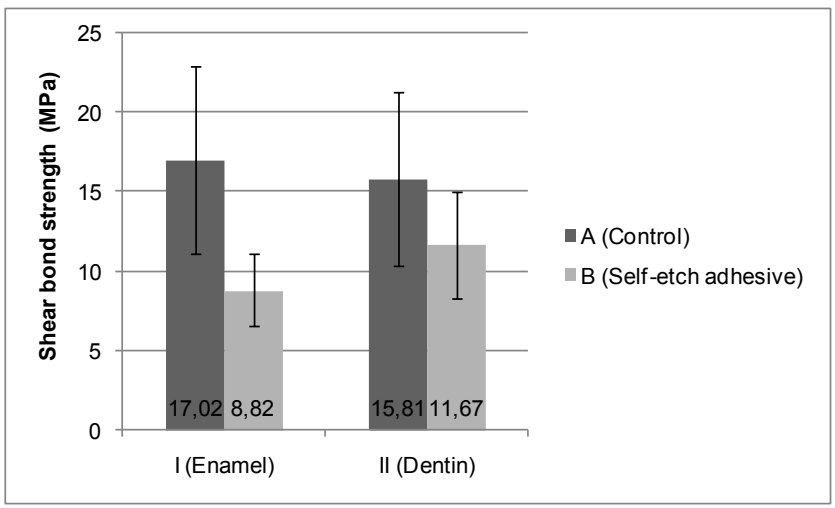

Fig. 1. Results of shear bond strength (MPa). 
Table 2. Distribution of failure modes as observed by optical microscopy

\begin{tabular}{ccccc}
\hline \multirow{2}{*}{ Failure Mode } & \multicolumn{2}{c}{ Enamel } & \multicolumn{2}{c}{ Dentin } \\
\cline { 2 - 5 } & $\begin{array}{c}\text { Adper Scotchbond } \\
(\%)\end{array}$ & $\begin{array}{c}\text { Adper Easy One } \\
(\%)\end{array}$ & $\begin{array}{c}\text { Adper Scotchbond } \\
(\%)\end{array}$ & $\begin{array}{c}\text { Adper Easy One } \\
(\%)\end{array}$ \\
\hline 1 & $2(28.6)$ & $7(100)$ & $3(42.9)$ & $5(71.4)$ \\
2 & $1(14.3)$ & $0(0)$ & $0(0)$ & $0(0)$ \\
3 & $4(57.1)$ & $0(0)$ & $4(57.1)$ & $2(28.6)$ \\
\hline
\end{tabular}

\section{Discussion}

The tested hypothesis was partially rejected. The 1 -step self-etch adhesive performed similarly to the etchand-rinse adhesive only for the dentin specimens. For the enamel specimens, the simplified application procedure underperformed compared with the conventional 3-step adhesive. These findings further support the idea that the etch-and-rinse approach remains the method of choice for the enamel substrate because it produces a more durable bond and protects the dentin against degradation $(3,10,11)$.

Among self-etch adhesives, the stronger adhesives perform fairly well on enamel, while mild adhesives so far remain unsatisfactory $(3)$. Adper Easy One $(\mathrm{pH} \approx 3.5)$ is an "ultramild" self-etch adhesive that only superficially interacts with enamel (12), which explains the lower bond strength values for specimens bonded with this material. Also for this group, all failure modes were classified as adhesive failures, confirming the poor performance of this adhesive system when bonded to enamel. Some authors suggest phosphoric acid preconditioning to improve the bond strength of low-pH self-etch adhesives at the enamel substrate $(13,14)$.

The findings of our study are consistent with those of Soderholm et al. (15), who found that the etch-andrinse adhesive performed better in vitro than self-etching adhesives. On dentin, Adper Scotchbond showed higher bond strength values; however, the difference was not statistically significant. Although a recent meta-analysis had concluded that 1-step self-etch adhesives still underperformed compared with conventional 3-step adhesives on dentin, our results showed that Adper Easy One performed on a par with the gold standard (8).

A 2-year, clinical trial on cervical lesions showed that a 1-step self-etch adhesive presented significantly more small enamel marginal defects and superficial marginal discoloration compared with a 3-step etch-and-rinse adhesive. However, the authors mentioned that these defects are clinically acceptable because they did not require intervention and could be easily removed by refinishing and repolishing. At the dentin margin, the adhesives behaved equally, in agreement with our study (12).

It should be noted that the earliest commercial self-etch adhesives were hydrophobic and did not adapt to dentin properly (16). Advances in composition of all-in-one adhesives improved their bonding ability. The chemistry to blend hydrophilic and hydrophobic monomers, solvents, water, and additives is complex $(17,18)$. However, nanosilica fillers form a resin film that stabilizes the hybrid layer (19). The intermediate layer of the adhesive filler promotes an elastic zone that improves the capacity to accommodate contractile forces during composite resin polymerization $(20,21)$. Also, functional monomers interact with $\mathrm{Ca}^{+2}$ to form apatite crystallites within the partially demineralized hybrid layer to form an insoluble calcium salt $(22,23)$. This chemical interaction between the hydroxyapatite or collagen and functional monomers in the adhesive might contribute to bond effectiveness of self-etch adhesives (24).

Within the limitations of this in vitro study, our results showed that the self-etch adhesive tested can be a good choice for dentin bonding. Although the optimal teeth to use for laboratory tests would be human teeth, bovine incisors are excellent substitutes in dental research because of their morphological and physiological similarities to human teeth (25). Further studies should be conducted to evaluate the long-term bonding durability of this adhesive system.

\section{Conclusions}

Adper Easy One showed lower shear bond strength than did Adper Scotchbond on an enamel substrate. For dentin, Adper Easy One had bond strength similar to that of Adper Scotchbond.

\section{Acknowledgments}

The authors would like to thank Antonio Ernandes Macêdo Paiva (Ph.D, Department of Mechanics and Materials [IFMA]) for his valuable assistance and FAPEMA for financial support (BM-00713/10). 
1. Van Meerbeek B, Perdigão J, Lambrechts P, Vanherle G. The clinical performance of adhesives. J Dent 1998;26:1-20.

2. Mine A, De Munck J, Cardoso MV, Van Landuyt KL, Poitevin A, Kuboki Tet al. Bonding effectiveness of two contemporary self-etch adhesives to enamel and dentin. J Dent 2009;37:872-83.

3. Van Meerbeek B, Yoshihara K, Yoshida Y, Mine A, De Munck J, Van Landuyt KL. State of art of self-etch adhesives. Dent Mater $2011 ; 27: 17-28$.

4. Unemori M, Matsuya Y, Akashi A, Goto Y, Akamine A. Composite resin restoration and postoperative sensitivity: clinical follow-up in an undergraduate program. J Dent 2001;29:7-13.

5. Unemori M, Matsuya Y, Akashi A, Goto Y, Akamine A. Self-etching adhesives and postoperatory sensitivity. Am J Dent 2004;17:191-5.

6. Van Meerbeek B, Willems G, Celis JP, Roos JR, Braem M, Lambrechts P, et al. Assessment by nanoindentation of the hardness and elasticity of the resin-dentin bonding area. J Dent Res 1993;72:1434-42.

7. Wei S, Shimada Y, Sadr A, Tagami J. Effect of double-application of three single-step selfetch adhesives on dentin bonding and mechanical properties of resin-dentin area. Oper Dent 2009;34:716-24.

8. Vanajasan PP, Dhakshinamoorthy M, Rao CS. Factors affecting the bond strength of selfetch adhesives: a meta-analysis of literature. J Conserv Dent 2011;14:62-7.

9. De Munck J, Van Landuyt K, Peumans M, Poitevin A, Lambrechts P, Braem M, et al. A critical review of the durability of adhesion to tooth tissue: methods and results. J Dent Res 2005;84:118-32.

10. Perdigao J, Lopes L, Lambrechts P, Leitao J, Van Meerbeek B, Vanherle G. Effects of a self-etching primer on enamel shear bond strengths and SEM morphology. Am J Dent 1997;10:141-6.

11. Miyazaki M, Sato M, Onose H. Durability of enamel bond strength of simplified bonding systems. Oper Dent 2000;25:75-80

12. Ermis RB, Van Landuyt KL, Cardoso MV, De Munck J, Van Meerbeek B, Peumans M. Clinical effectiveness of a one-step self-etch adhesive in non-carious cervical lesions at 2 years. Clin Oral Invest 2011 [Epub ahead of print].

13. Peumans M, De Munck J, Van Landuyt KL, Poitevin A, Lambrechts P, Van Meerbeek B. Eight-year clinical evaluation of a two-step self-etch adhesive with and without selective enamel etching. Dent Mater 2010;26:1176-84.

14. Rotta M, Bresciani P, Moura SK, Grande RH, Hilgert LA, Baratieri LN et al. Effects of phosphoric acid pretreatment and substitution of bonding resin on bonding effectiveness of self-etching systems to enamel. J Adhes Dent 2007;9:537-46.

15. Söderholm KM, Soares F, Argumosa M, Loveland C, Bimsteim E, Guelmann M. Shear bond strength of one etch-and-rinse and five self-etching dental adhesives when used by six operators. Acta Odontol Scan 2008:66;243-9.

16. Albaladejo A, Osorio R, Toledano M, Ferrari M. Hybrid layers of etch-and-rinse versus self-etching adhesive systems. Med Oral Patol Oral Cir Bucal 2010;15:112-8.

17. Van Meerbeek B, De Munck J, Yoshida Y, Inoue S, Vargas M, Vijay P, et al. Buonocore Memorial Lecture. Adhesion to enamel and dentin: current status and future challenges Oper Dent 2003;28(3):215-35.

18. Amaral RC, Stanislawczuk R, Zander-Grande C, Gagler D, Reis A, Loguercio AD. Bond strength and quality of the hybrid layer of one-step self-etch adhesives applied with agitation on dentin. Oper Dent 2010;35-2:211-19.

19. Cardoso PE, Carrilho MRO, Francci CE, Perdigao J. Microtensile bond strengths of onebottle dentin adhesives. Am J Dent 2001;14:22-4.

20. Miyazaki M, Ando S, Hinoura K, Onose H, Moore BK. Influence of filler addition to bonding agents on shear bond strength to bovine dentin. Dent Mater 1995; 1 1:234-8.

21. Villela-Rosa ACM, Gonçalves M, Orsi IA, Miani PK. Shear bond strength of self-etch and total-etch bonding systems at different dentin depths. Braz Oral Res 2011 ;25:109-15.

22. Ikemura K, Tay FR, Kouro Y, Endo T, Yoshiyama M, Miyai K, et al. Optimizing filler content in an adhesive system containing pre-reacted glass-ionomer fillers. Dent Mater 2003; 19:137-46.

23. Yoshida Y, Van Meerbeek B, Nakayama Y, Snauwaert J, Hellemans L, Lambrechts $P$, et al. Evidence of chemical bonding at biomaterial-hard tissue interfaces. J Dent Res 2000;79:709-14.

24. Ikeda M, Kurokawa H, Sunada N, Tamura Y, Takimoto M, Murayama R, et al. Influence of previous acid etching on dentin bond strength of self-etch adhesives. J Oral Sci 2009;51:527-34.

25. Campos MIC, Campos CN, Vitral RWF. The use of bovine teeth as a substitute for human teeth in dentistry research: a review of literature. Pesq Bras Odontoped Clin Integr 2008;8:127-32. 